\title{
Fitness components of a recently-established population of Zaprionus indianus (Diptera, Drosophilidae) in Brazil
}

\author{
Nathalia de Setta \& Cláudia M. A. Carareto
}

Departamento de Biologia, IBILCE, Universidade Estadual Paulista, Rua Cristóvão Colombo, 2265, 15054-000 São José do Rio Preto, SP. (nsetta@hotmail.com; carareto@bio.ibilce.unesp.br)

\begin{abstract}
This study aimed to evaluate fitness components of Zaprionus indianus Gupta, 1970, a species recently introduced in Brazil and currently in process of colonization. Longevity, productivity, developmental speed and viability of flies sampled from a population from Mirassol (state of São Paulo, Brazil) were evaluated. Longevity was higher than that of some Indian populations and productivity was similar or higher than in other Drosophilidae. Time of development, one of the main fitness components for competition, was very similar to the values scored in Drosophila sturtevanti Duda, 1927, a species that occurs in high frequencies in the same area as $Z$. indianus. These data might contribute further for understanding the colonization success of this newcomer species in South America.
\end{abstract}

KEYWORDS. Fitness components, productivity, viability, time of development, Zaprionus.

RESUMO. Componentes do valor adaptativo de uma população recentemente estabelecida no Brasil de Zaprionus indianus (Diptera, Drosophilidae). Neste estudo foram avaliados componentes do valor adaptativo de Zaprionus indianus Gupta, 1970, uma espécie recentemente introduzida no Brasil e, atualmente, em processo de colonização de praticamente todas as regiões brasileiras. Foram avaliadas a longevidade, a produtividade, a velocidade de desenvolvimento e a viabilidade de indivíduos amostrados de uma população de Mirassol (estado de São Paulo, Brasil). A longevidade foi maior do que aquelas registradas em populações indianas, enquanto que a produtividade foi similar ou maior do que a observada em outros Drosophilidae. O tempo de desenvolvimento, um dos principais componentes relacionados à habilidade competitiva, foi muito similar aos valores registrados para Drosophila sturtevanti Duda, 1927, espécie que ocorre em alta frequiência na mesma área que Z. indianus. Esses dados podem contribuir para o entendimento do sucesso de colonização desta espécie recém-introduzida na América do Sul.

PALAVRAS-CHAVE: Componentes do valor adaptativo, produtividade, viabilidade, tempo de desenvolvimento, Zaprionus.

Zaprionus Coquillett, 1901 is a genus composed by the subgenera Zaprionus, which contains 44 species from Afrotropical region (CHASSAGNARD \& TSACAS, 1993; Chassagnard, 1996) and Anaprionus, with 12 species from Australia and Southeastern Asia (Tsacas \& Chassagnard, 1990; Gupta \& GupTA, 1991). Zaprionus indianus seems to be the unique species of Zaprionus subgenus that is spreading throughout the tropical regions, probably due to the intensification of the world fruit commerce (VILELA et al., 2001). This species occurs throughout Africa, India and Saudi Arabia, as well as in islands of the Indian Ocean (Comores, Madagascar, Seychelles, Mauritius and Réunion) and of the Atlantic Ocean (Canary and Saint Helena) (Chassagnard \& Kraaijeveld, 1991; Chassagnard \& Tsacas, 1993). In Africa, it has been found in 74 species of 31 botanical families; among them, several are native of the American continent (avocado, pineapple, guava and papaya) or have been here introduced (carambola, banana, citrus, mango and fig) (LACHAISE \& TSACAS, 1983).

The occurrence of $Z$. indianus in South America was first reported in Brazil (VILELA, 1999) and then in Uruguay (GoÑ et al., 2001). It has been suggested that this species may have been introduced in Brazil by airplane transportation from African or Asian countries to the city of São Paulo, possibly in meals (fruits for instance) offered to passengers (VILELA, 1999; Tidon et al., 2003). Zaprionus indianus has been found in all regions of Brazil (CASTRO \& VALENTE, 2001; VIlela, 1999; Vilela et al., 2001; Tidon et al., 2003).
Although Z. indianus has not been considered as a pest in the Afrotropical region, it seems to be reaching the pest status in the fig main producer areas of the state of São Paulo (Brazil). In 1999, 50\% of the fig crops were lost due to oviposition of these flies (VILEla et al., 2001). Since Z. indianus has also been found in other tropical fruits, such as citrus, persimmon, guava, jambul and acerola (VILELA et al., 2001), it is possible that this species will become invasive in the culture of these agricultural products, thus causing damages to regional economies.

Little information about $Z$. indianus reproductive biology is found in the literature. Therefore, the quantification of fitness components in laboratory is an important tool to evaluate the life-history parameters and the strategies used by exotic species to establish themselves into new habitats. Since $Z$. indianus quickly spread throughout the Brazilian regions, the aim of this study was to evaluate five fitness components of $Z$. indianus taking as a sample a population of the northwest of São Paulo state. This study might provide essential information to identify the factors responsible for its fast spreading throughout the Neotropical region.

\section{MATERIAL AND METHODS}

Zaprionus indianus was collected in Mirassol, São Paulo State, Brazil (20 $\left.47^{\prime} \mathrm{S}, 49^{\circ} 30^{\prime} \mathrm{W}\right)$ in April and May 2001. About 100 collected females were put individually 
in vials with banana-agar medium and maintained at $25^{\circ} \mathrm{C}$ until the imagoes emergence. Virgin males (150) and females (150) emerged from these vials were used to study longevity of sexually active and sexually inactive flies, productivity and developmental speed. The remained flies were used to set up a mass culture that was maintained in constant room temperature at $25^{\circ} \mathrm{C}$.

For the study of longevity of sexually active flies, 50 one day old couples of virgin flies, were placed pair by pair into vials containing culture medium, and transferred to new vials at intervals of seven days until their death. Longevity of sexually inactive flies was studied in a similar way, putting together two virgin males or two virgin females in each vial to maintain the same number of individuals as in the studies of sexually active flies. The $F_{1}$ offspring of 32 couples used in the longevity experiment were scored to study productivity, by sex, until their death. These vials were also daily observed to estimate the period of time for the emergence of the first imago as a way to estimate the speed of development. Since each female could lay eggs in every of the seven days in which the couple was maintained in the vial, the period of time for the emergence of the first imago was considered as the number of days between the entrance of the couple in the vial and the first emergence minus 3.5 days (the average period of oviposition in each vial).

In order to study time of development and viability, a population cage (a transparent plastic box $19 \mathrm{~cm}$ long, $15 \mathrm{~cm}$ wide and $12 \mathrm{~cm}$ high) was set up with flies that had been maintained in laboratory mass culture during six generations. The eggs were collected from the population cage in which females were allowed to lay eggs in plastic dishes containing culture medium for a period of $12 \mathrm{~h}$. The dishes were closed and stored for three days at 25 ${ }^{\circ} \mathrm{C}$. The hatched larvae were transferred, in groups of 20 , to 20 vials with culture medium, performing a total of 400 larvae. The number of pupae on the wall of the vial and on the surface of the culture medium was daily counted, as well as the number of emerged adults. These data were used to estimate the time of development from egg to pupa, from pupa to imago, and from egg to imago. The numbers of pupae and adults yielded in each vial were used to calculate the larva-pupa and pupa-imago viabilities (the percentage of pupae and emerged imagoes in each vial). For estimating the egg-larva viability, 1000 fertilized eggs were taken from the population cage. The fertilized eggs, identified by their characteristic turgescence and pale coloration, were put in groups of 10 in 10 petri dishes and $48 \mathrm{~h}$ later the egg-larva viability was estimated as the percentage of hatched larvae in each dish.

The Student t-test was used for testing the differences between means of longevity and one-way ANOVA was used for testing homogeneity of the developmental speed means. The Tukey multiple comparisons test (ZAR, 1984) was applied to evaluate the statistical differences among the means of developmental speed. Analyses of linear correlation were done to estimate association between longevity of males and females and their productivity.

\section{RESULTSAND DISCUSSION}

There are few studies about longevity of $Z$. indianus. The values found in literature are those of control groups used for investigation of effects of various antioxidants on the lifespan and ageing characteristics of Z. paravittiger Godbole and Vaidya, $1972(=Z$. indianus). According to SHARma et al. (1995), the mean longevity for males and females kept in the same vial is 30.6 days (maximum lifespan: 70 days) and 34.3 days (maximum lifespan: 76 days) respectively; values very similar to those obtained by KAKKAR et al. (1996), 35.1 days for males and 41.7 days for females. Both studies were made in corn-meal agar medium at $26 \pm 2{ }^{\circ} \mathrm{C}$.

Longevity of virgin males of $Z$. indianus emerged in laboratory ranged from 7 to 138 days $(68.0 \pm 3.4)$, whereas longevity of virgin females ranged from 7 to 154 days $(97.5 \pm 3.0)$. Survival of males and females kept in the same vial ranged from 11 to 150 days $(81.7 \pm 5.0)$ for males, and from 4 to 145 days $(92.6 \pm 4.6)$ for females. In both situations, longevity was higher than that observed by SHARMA et al. (1995) and KAKKAR et al. (1996). Females lived longer than males, however the differences were significant only for virgin flies $(\mathrm{t}=6.39 ; P<0.01)$. The mortality slopes of the four groups of flies analyzed showed a similar pattern, however, as a group, males died earlier than females, irrespective of their reproductive state (fig. 1). This relation is commonly found in insects (LiNTs et al., 1983).

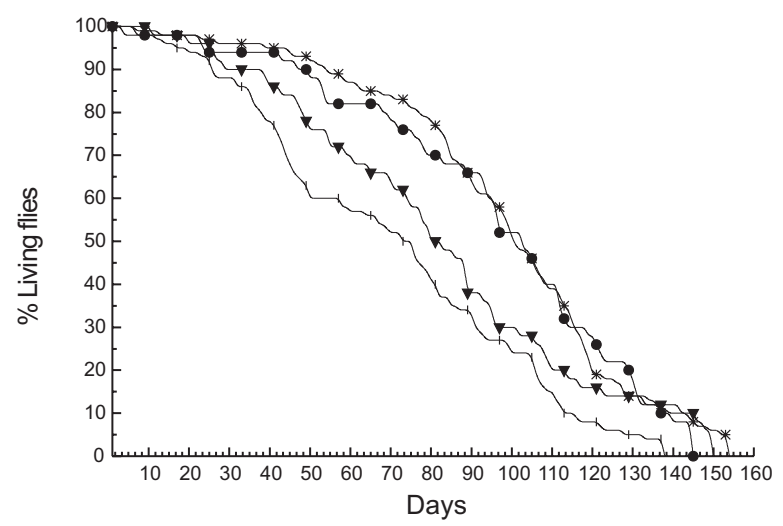

Fig. 1. Mortality slopes of males and females in Zaprionus indianus (sexually active males: - $-\mathbf{\nabla}$; sexually active females: — - - ; sexually inactive males: $\_-1$; sexually inactive females: - * -).

The differences among the mean longevity of flies with and without sexual activity were not significant $(\mathrm{t}=2.33 ; P>0.05$ for males and $\mathrm{t}=0.73 ; P>0.05$ for females). It is commonly accepted that reproduction in animals and plants should have a cost: the larger the reproductive activity, the shorter the duration of life. But, the causes of this difference are not easily understood; in males of $D$. melanogaster Meigen, 1830, it was suggested to be a consequence of a physiologic depletion, caused by sperm and seminal fluid production (PARTRIDGe \& FARQUHAR, 1981); in females, it could be a 
consequence of the allocation of energy for egg production or to detrimental effects of the mating (PARTRIDGE et al., 1987). However, the findings about the association between longevity and sexual activity are very contradictory. Negative or positive correlations as well as absence of correlation have been found between these traits (MaLicK \& Kidwell, 1966; Kidwell \& Malick, 1967; CARARETo \& Mourão, 1992). The absence of correlation observed in our study could mean that the energy that has not been allocated for reproduction has not been used for increasing the lifespan of Z. indianus.

Productivity was evaluated by the mean number of adults yielded at seven days of oviposition during the whole life of the female. The individual productivity ranged from 16 to 103 flies. Each couple produced 57.5 offspring in average during its fertile period, which ranged from 2 to 14 weeks (tab. I). In our laboratory, productivity of Drosophila species ranged from 12 to 68 individuals per couple. In D. mulleri Sturtevant, 1921, a species of the subgenus Drosophila, two homozygous strains for the $\beta$ esterases yielded $33.7\left(\right.$ Est- $\left.4^{\mathrm{S}}\right)$ and $68.2\left(\right.$ Est- $\left.4^{\mathrm{F}}\right)$ individuals (LouRENÇO et al., 2001); in the subgenus Sophophora, the mean productivity of three strains of D. prosaltans, ranged from 30 to 68 imagoes per female (CARAReto \& Mourão, 1991), and the mean productivity four strains of $D$. sturtevanti, homozygous for inversions, ranged from 12 to 63.9 imagoes (CARARETO \& Mourão, 1992) in average. These values show that $Z$. indianus has practically the same productivity as other analyzed

Table I. Number of imagoes (males and females) yielded by each couple, productivity and duration of fertile period (in weeks) of Zaprionus indianus ( $\overline{\mathrm{x}}$, mean; se, standard error).

\begin{tabular}{|c|c|c|c|c|}
\hline \multirow[t]{2}{*}{ Couples } & \multirow{2}{*}{$\begin{array}{l}\text { Fertile } \\
\text { Period } \\
\text { (weeks) }\end{array}$} & \multicolumn{3}{|c|}{ Productivity } \\
\hline & & Males & Females & Total \\
\hline 1 & 8 & 28 & 35 & 63 \\
\hline 2 & 7 & 35 & 39 & 74 \\
\hline 3 & 10 & 27 & 28 & 55 \\
\hline 4 & 13 & 15 & 30 & 45 \\
\hline 5 & 14 & 11 & 39 & 50 \\
\hline 6 & 10 & 9 & 9 & 18 \\
\hline 7 & 9 & 12 & 13 & 25 \\
\hline 8 & 12 & 25 & 25 & 50 \\
\hline 9 & 12 & 21 & 39 & 60 \\
\hline 10 & 11 & 17 & 44 & 61 \\
\hline 11 & 11 & 3 & 13 & 16 \\
\hline 12 & 10 & 23 & 19 & 42 \\
\hline 13 & 11 & 28 & 37 & 65 \\
\hline 14 & 10 & 38 & 53 & 91 \\
\hline 15 & 11 & 13 & 23 & 36 \\
\hline 16 & 10 & 26 & 44 & 70 \\
\hline 17 & 10 & 21 & 37 & 58 \\
\hline 18 & 9 & 12 & 19 & 31 \\
\hline 19 & 8 & 51 & 49 & 100 \\
\hline 20 & 8 & 30 & 14 & 44 \\
\hline 21 & 7 & 23 & 47 & 70 \\
\hline 22 & 7 & 46 & 57 & 103 \\
\hline 23 & 7 & 23 & 52 & 75 \\
\hline 24 & 6 & 47 & 41 & 88 \\
\hline 25 & 5 & 38 & 33 & 71 \\
\hline 26 & 4 & 37 & 37 & 74 \\
\hline 27 & 3 & 22 & 19 & 41 \\
\hline 28 & 3 & 19 & 29 & 48 \\
\hline 29 & 2 & 18 & 25 & 43 \\
\hline$\overline{\mathrm{X}} \pm \mathrm{se}$ & $8.6 \pm 0.6$ & $24.8 \pm 2.2$ & $32.7 \pm 2.4$ & $57.5 \pm 4.2$ \\
\hline
\end{tabular}

species of Drosophilidae. Zaprionus indianus females were produced in higher number $(32.7 \pm 2.4)$ than males $(24.8 \pm 2.2 ; \mathrm{t}=2.42 ; P<0.05)$.

Our data suggest that the reproductive effort of $Z$. indianus females does not affect their longevity because productivity was positively correlated to the maternal longevity $(\mathrm{r}=0.376 ; \mathrm{t}=2.11 ; P<0.05)$, but not to the paternal one $(\mathrm{r}=0.333 ; \mathrm{t}=1.84 ; P>0.05)$. Agreements and disagreements of associations among longevity, sexual activity and productivity are equally found. It is possible that the correlation analysis values simply reflect particularities of the different species as well as the environmental conditions of the experiments.

The mean developmental speed of the offspring yielded by parents in different periods of their lives varied significantly during the 14 fertile weeks (mean: $12.7 \pm 0.3$ days $\left.; \mathrm{F}_{12 ; 229}=6.99 ; P<0.01\right)$. The developmental speeds ranging from $16.3 \pm 0.5$ days (one week old parents) to $11.2 \pm 0.4$ days ( 7 and 11 week old parents), suggests that the younger the parents, the slower the developmental speed of the progeny. However, the values from the second week of age on ranged very irregularly, from 11.2 \pm 0.4 days $\left(7^{\text {th }}\right.$ and $11^{\text {th }}$ weeks $)$ to $14.2 \pm 0.9\left(13^{\text {th }}\right.$ week $)$. The pairwise comparisons of the 14 week means (Tukey's test, $\mathrm{a}=0.05$ ) indicated that the significance observed is due only to the mean value of the first week $(\mathrm{dms}=4.68$; $P<0.05$ ). If the values of the first week are not used, the difference among the remaining 13 means becomes not significant $\left(\mathrm{F}_{11 ; 199}=1.34 ; P>0.05\right.$ and $\mathrm{dms}=2.57 ; P>$ $0.05)$. These results indicate that the slower developmental speed in offspring of parents one day old is not a real value. In fact, the slower developmental speed observed in the first week of emergence might result from the variation in sexual maturity of the couples. Since the flies in the beginning of the study were one day-old and each one could have reached sexual maturity in different periods during the permanence in the vial, the mean time for the emergence of the first imago in those vials would be higher than those in the following weeks, because after seven days all flies should have reached sexual maturity and should be able to lay eggs as soon as they were placed into the vials.

The development time (days) at $25^{\circ} \mathrm{C}$ for egg-pupa, pupa-imago and egg-imago periods varied from 9 to 15 days for the egg-pupa developmental time, 3 to 10 days for the pupa-imago, and from 15 to 25 days for the eggimago; the mean values were 12.7, 5.8 and 18.5 days, respectively (tab.II). The egg-imago development time was very close to the values recorded in Drosophila sturtevanti (19.6 days; CARARETO et al., 1999) or higher to those observed in D. melanogaster (8.41 days; Woods et al., 2002) and D. simulans Sturtevant, 1919 (8.36 days; Woods et al., 2002) at the same temperature. These species occur in high frequencies in the same area where Z. indianus has been collected. Competitive interactions among pre-adult stages of Z. indianus, D. sturtevanti and $D$. simulans, showed that the development time of $D$. sturtevanti and of $D$. simulans was reduced in the presence of $Z$. indianus residues in the culture medium. It suggests a positive effect of the larval residues on development of $Z$. indianus larvae (Luís Gustavo da 
Conceição Galego \& Cláudia Márcia Aparecida Carareto, pers. comm.).

Viability at $25{ }^{\circ} \mathrm{C}$ was scored for several developmental stages including egg-larvae, larvae-pupa, pupa-imago and larvae-imago periods. The larva-pupa viability ranged from $60 \%$ to $100 \%$, the larva-imago from $35 \%$ to $95 \%$ and the pupa-imago, calculated by subtracting the values of the first two estimates, ranged from $50 \%$ to $100 \%$ (tab. II). The egg-larva viability, which was scored in an independent study, ranged from 55\% to $96 \%$ with mean value of $72.5 \%$, representing the stage of development with the highest loss of offspring.

It seems that $Z$. indianus individual productivity in laboratory is unexpectedly low, considering the capacity of dispersion of this species. Since it has been found in high numbers in almost all regions of Brazil, we should expect reproductive parameters with values that could favor high production of offspring in a short period of time. However, it has been reported that this species has remarkable population size contractions during dry seasons (TIDON et al., 2003). The low productivity scored could be due to the laboratory conditions, such as the culture medium used and/or the temperature (controlled) and humidity (uncontrolled), having the latter probably the main effect. Hence, these environmental factors might be important for controlling population size of $Z$. indianus in the several South American regions where it has been found. These data might contribute for understanding the colonization success of this newcomer species in South America.

Table II. Viability and time of development of Zaprionus indianus (E-I, egg-imago; E-L, egg-larvae; E-P, egg-pupa; L-I, larvae-imago; L-P, larvae-pupa; P-I, pupa-imago; $\overline{\mathrm{x}}$, mean; se, standard error; *, viability was obtained independently in studies other that the present one).

\begin{tabular}{|c|c|c|c|c|c|c|c|}
\hline \multirow{2}{*}{$\begin{array}{l}\text { Vials/ } \\
\text { Dishes }\end{array}$} & \multicolumn{4}{|c|}{ Viability (\%) } & \multicolumn{3}{|c|}{ Time of Development (Days) } \\
\hline & E-L* & L-P & P-I & L-I & E-P & P-I & E-I \\
\hline 1 & 69 & 95 & 52.6 & 50 & 12 & 3 & 15 \\
\hline 2 & 75 & 100 & 50.0 & 50 & 9 & 6 & 15 \\
\hline 3 & 67 & 75 & 73.3 & 55 & 11 & 6 & 17 \\
\hline 4 & 69 & 75 & 73.3 & 55 & 11 & 5 & 16 \\
\hline 5 & 82 & 75 & 80.0 & 60 & 12 & 6 & 18 \\
\hline 6 & 63 & 75 & 93.3 & 70 & 14 & 5 & 19 \\
\hline 7 & 65 & 80 & 93.7 & 75 & 14 & 4 & 18 \\
\hline 8 & 55 & 100 & 95.0 & 95 & 12 & 7 & 19 \\
\hline 9 & 84 & 75 & 93.3 & 70 & 12 & 7 & 19 \\
\hline 10 & 96 & 80 & 100.0 & 80 & 12 & 7 & 19 \\
\hline 11 & & 80 & 93.7 & 75 & 13 & 6 & 19 \\
\hline 12 & & 100 & 65.0 & 65 & 14 & 6 & 20 \\
\hline 13 & & 80 & 87.5 & 70 & 12 & 7 & 19 \\
\hline 14 & & 70 & 78.5 & 55 & 15 & 4 & 19 \\
\hline 15 & & 75 & 100.0 & 75 & 15 & 8 & 23 \\
\hline 16 & & 80 & 87.5 & 70 & 15 & 10 & 25 \\
\hline 17 & & 90 & 94.4 & 85 & 13 & 5 & 18 \\
\hline 18 & & 70 & 71.4 & 50 & 14 & 5 & 19 \\
\hline 19 & & 60 & 58.3 & 35 & 11 & 6 & 17 \\
\hline 20 & & 80 & 93.7 & 75 & 13 & 3 & 16 \\
\hline$\overline{\mathrm{x}} \pm \mathrm{se}$ & $72.5 \pm 3.8$ & $80.7 \pm 2.4$ & $81.7 \pm 3.5$ & $65.7 \pm 3.2$ & $12.7 \pm 0.3$ & $5.8 \pm 0.4$ & $18.5 \pm 0.5$ \\
\hline
\end{tabular}

Acknowledgments. To CNPq for the PIBIC fellowship to Nathalia de Setta.

\section{REFERENCES}

Carareto, C. M. A.; Lourenço, M. F. \& Mourão, C. A. 1999. Sensitivity of fitness to variation in its components in Drosophila sturtevanti (Diptera, Drosophilidae). Iheringia, Série Zoologia, 87:37-48.

Carareto, C. M. A. \& Mourão, C. A. 1991. Darwinian fitness in Drosophila. I. Fitness components of Drosophila prosaltans. Revista Brasileira de Genética, 14(3):661-672.

1992. Darwinian fitness in Drosophila. III. Fitness components of Drosophila sturtevanti. Revista Brasileira de Genética, 15(2):323-338.

Castro, F. L. \& Valente, V. L. S. 2001. Zaprionus indianus is invading Drosophilid communities in the southern Brazilian city of Porto Alegre. Drosophila Information Service, 84:15-17.

Chassagnard, M. T. 1996. Les espèces africaines du sous-genre Zaprionus s. str. À six bandes thoraciques (Diptera: Drosophilidae). Annales Société Entomologique de France, 32(1):59-65.
Chassagnard, M. T. \& Kranijeveld, A. R. 1991. The occurrence of Zaprionus s. str. in the Palearctic region (Diptera: Drosophilidae). Annales Société Entomologique de France, 27(4):495-496.

Chassagnard, M. T. \& Tsacas, L. 1993. Le sous-genre Zaprionus s. str. Définition de groupes d'espècies et révision du sousgoup vittiger (Diptera: Drosophilidae). Annales Société Entomologique de France, 29(2):173-194.

Goñi, B.; Fresia, P.; Calviño, M.; Ferreiro, M. J.; Valente, V. L. S. \& Silva, L. B. DA. 2001. First record of Zaprionus indianus Gupta, 1970 (Diptera: Drosophilidae) in southern localities of Uruguay. Drosophila Information Service, 84:61-65.

Gupta, K. K. \& Gupta, J. P. 1991. Four new and two unrecorded species of Drosophilidae from India (Insecta: Diptera). Proceedings of the Zoological Society, 44:119-126.

KakKar, R.; Bains, J. S. \& Sharma, S. P. 1996. Effect of vitamin E on life span, malondialdehyde content and antioxidant enzymes in aging Zaprionus paravittiger. Gerontology, 42:312-321.

Kidwell, J. F. \& Malick, L. E. 1967. The effects of genotype, mating status, weight and egg production on longevity in Drosophila melanogaster. Journal of Heredity, 58:169-172. 
Lachaise, D. \& Tsacas, L. 1983. Breeding-sites in tropical African drosophilids. In: Ashburner, M.; CArson, H. L. \& Thompson, J. N. eds. The genetics and biology of Drosophila. London, Academic Press. p.221-332.

Lints, F. A.; Bourgois, M.; Delalieux, A.; Stoll, J. \& Lints, C. V. 1983. Does the female life span exceed that of the male? A study in Drosophila melanogaster. Gerontology, 29(5):336-352.

Lourenço, M. F.; Ceron, C. R. \& Carareto, C. M. A. 2001. Evaluation of fitness components in strains of Drosophila mulleri carrying different genotypes for an esterase. Cytobios, 106(412): 125-138.

Malick, L. E. \& Kidwell, J. F. 1966. The effects of mating status, sex and genotype on longevity in Drosophila melanogaster. Genetics, 54:203-209.

Partridge, L. \& Farquhar, M. 1981. Sexual activity reduces lifespan of male fruit flies. Nature, 294:580-582.

Partridge, L.; Green, A. \& Fowler, K. 1987. Effects of eggproduction and exposure to males on female's survival in Drosophila melanogaster. Journal of Insect Physiology, 33:745-749.

Sharma, S. P.; Sharma, M. \& Kakkar, R. 1995. Methionineinduced alterations in the life span, antioxidant enzymes, and peroxide levels in aging Zaprionus paravittiger. Gerontology, 41:86-93.

Tidon, R.; Leite, D. F. \& LeÃo, B. F. D. 2003. Impact of the colonisation of Zaprionus (Diptera: Drosophilidae) in different ecosystems of the Neotropical Region: 2 years after the invasion. Biological Conservation, 112:299-305.

Tsacas, L. \& Chassagnard, M. T. 1990. Les espèces du genre Zaprionus à fémurs antérieurs spinuleux (Diptera: Drosophilidae). Annales Société Entomologique de France, 26:461-487.

Vilela, C. R. 1999. Is Zaprionus indianus Gupta 1970 (Diptera, Drosophilidae) currently colonizing the Neotropical region? Drosophila Information Service, 82:37-39.

Vilela, C. R.; Teixeira, E. P. \& Stein, C. P. 2001. Mosca-africana-dofigo, Zaprionus indianus (Diptera: Drosophilidae). In: ViLela, E.F.; ZuCCHI, R.A. \& CANTOR, F. eds. Histórico e impacto das pragas introduzidas no Brasil. Ribeirão Preto, Holos. p.48-52.

Woods, R. E.; Sgrò, C. M.; Hercus, M. \& Hoffmann, A. A. 2002. Fluctuating asymmetry, fecundity and development time in Drosophila: is there an association under optimal and stress conditions? Journal of Evolutionary Biology, 15:146-157.

ZAR, J. H. 1984. Biostatistical analysis. 2.ed. New Jersey, Prentice-Hall. 718p.

Recebido em março de 2004. Aceito em dezembro de 2004. ISSN 0073-4721

Artigo disponível em: www.scielo.br/isz 